Sains Malaysiana 50(6)(2021): 1577-1588

http://doi.org/10.17576/jsm-2021-5006-06

\title{
Zooplankton Community Structure in Relation to the Water Quality and Seston Fatty Acid Content in the Coastal Waters of Penang, Malaysia
}

(Struktur Komuniti Zooplankton Berkaitan dengan Kualiti Air dan Kandungan Asid Lemak Seston di Perairan Pantai Pulau Pinang, Malaysia)

\section{WAN MAZNAH, W. O.*, NUR ‘AIN KASSIM \& ZUBIR DiN}

\begin{abstract}
Zooplankton community structure and seston fatty acid content in relation with water quality characteristics at selected sampling stations of Penang coastal waters were determined. Water and zooplankton samples were collected on five sampling occasions from July 2009 until April 2011. Zooplankton samples were collected by horizontal towing with plankton net (WP-2) and a fraction of the samples was used to get seston population for fatty acid analysis. Phylum Arthropoda dominated the sampling area with $78.80 \%$ of relative abundance, where Copepoda was the most abundant. Other phyla such as Chordata (9.10\%), Cycliophora (6.12\%), Actinopoda (2.08\%), Rotifera (2.57\%), Annelida (0.63\%), Cnidaria (0.51\%), and Chaetognatha (0.19\%) were accounted in small abundance. Kuala Juru Station, which was highly impacted by human activities had the highest relative abundance and Jerejak Station (control station and considered to have low impact by anthropogenic activities) had the lowest relative abundance. Zooplankton diversity was quite low at all stations, might be due to large abundance of dominant taxa. The dominant fatty acid methyl esters (FAMEs) detected on seston consisted of SAFA (C16:0, C14:0, and C18:0), MUFA (C16:0, C14:0, and C18:0), PUFA (C18:2n6c and C20:5n3) and HUFA (C22:6n3 or DHA). Zooplankton community was influenced by food availability (phytoplankton, as measured by chlorophyll a and fatty acid composition in seston) and water quality.
\end{abstract}

Keywords: Arthropoda; fatty acid; Malaysia; Rotifera; zooplankton diversity

ABSTRAK

Struktur komuniti zooplankton dan kandungan asid lemak seston berkaitan dengan ciri-ciri kualiti air di stesen pensampelan terpilih di perairan pantai Pulau Pinang telah ditentukan. Sampel air dan zooplankton dikumpulkan pada lima stesen persampelan dari Julai 2009 hingga April 2011. Sampel zooplankton dikumpulkan dengan cara menunda secara mendatar menggunakan jaring plankton (WP-2) dan sebahagian dari sampel digunakan untuk analisis asid lemak populasi seston. Phylum Arthropoda mendominasi kawasan persampelan dengan 78.80\% kelimpahan relatif dengan Copepoda adalah yang paling banyak. Phyla lain seperti Chordata (9.10\%), Cycliophora (6.12\%), Actinopoda (2.08\%), Rotifera (2.57\%), Annelida (0.63\%), Cnidaria (0.51\%) dan Chaetognatha (0.19\%) terdapat dalam kelimpahan yang kecil. Stesen Kuala Juru, yang sangat dipengaruhi oleh aktiviti manusia mempunyai kelimpahan relatif tertinggi dan Stesen Jerejak (stesen kawalan dan dianggap mempunyai kesan yang rendah oleh aktiviti antropogenik) mempunyai kelimpahan relatif terendah. Kepelbagaian zooplankton agak rendah di semua stesen, mungkin disebabkan oleh kepelbagaian taksonomi yang dominan. Asid lemak metil ester (FAMEs) dominan yang dikesan pada plankton terdiri daripada SAFA (C16: 0, C14: 0 dan C18: 0), MUFA (C16: 0, C14: 0 dan C18: 0), PUFA (C18: 2n6c dan C20: 5n3) dan HUFA (C22: $6 n 3$ atau DHA). Komuniti zooplankton dipengaruhi oleh ketersediaan makanan (fitoplankton, seperti yang diukur oleh klorofil a dan komposisi asid lemak seston) dan kualiti air.

Kata kunci: Arthropoda; asid lemak; kepelbagaian zooplankton; Malaysia; Rotifera

\section{INTRODUCTION}

Zooplankton plays an important role in the aquatic ecosystem as a secondary producer. The freshwater forms of zooplankton are smaller in size than of marine counterparts, as the marine zooplankton are represented by vast animal phyla. This includes various protozoa, Rotifera, Cladocera, Copepoda, Ostracoda and also meroplankton such as insect larvae (Davies \& Otene 2009). 
A slight change in the concentration and composition of zooplankton might show a subtle change of environment. Zooplankton are highly responsive to factors such as nutrient levels, temperatures, food availability, pollution, light intensities, predation, $\mathrm{pH}$ levels, and heavy metals. Nutrients, particularly nitrogen and phosphorus affect the prey of zooplankton which are most commonly consist of algae, protozoa, and bacteria; subsequently affecting the survival of zooplankton. Besides playing an important role in the marine food chain, zooplankton community attributes can be used as bioindicators of aquatic ecosystem health (Steinberg \& Landry 2017; Wan Maznah et al. 2018).

Fatty acids are particularly useful biomarkers since they are essential components of all living cells and display a high structural diversity with higher level taxonomic specificity (Colombo et al. 2016). The use of fatty acid composition as a reliable method for tracing the food source through multiple food web linkages has been applied by the conservative transfer of tracer fatty acids from phytoplankton to copepods (Persson \& Vrede 2006; Werbrouck et al. 2016). A useful biomarker must be synthesized at low trophic levels and remain unchanged when transferred to higher trophic levels (Napolitano et al. 1997). Fatty acids can be used to distinguish bacteria, phytoplankton classes and zooplankton orders in marine samples (Bergé \& Barnathan 2005; Brett et al. 2009). The long-chain polyunsaturated fatty acids are especially useful, since these fatty acids cannot be synthesized de novo in sufficient amounts by the predators.

The rapid changes in the natural environment in Malaysia were mainly driven by the continued eco-social growth and industrialization, and these changes have resulted in serious negative impacts on the coastal area. Penang Island is the second biggest island in Malaysia after Langkawi Island. Penang State is made up of two separate physical entities which are Penang Island that covers an area of 293 square kilometers and Seberang
Perai on the mainland covers an area of 738 square kilometers (Figure 1). To date, little scientific studies have taken place and no data are available on zooplankton communities at the coastal areas of Penang. Therefore, this study was conducted to provide a comprehensive evaluation of the zooplankton community structure and seston fatty acid content at selected sampling stations, to provide a baseline data on ecological status of Penang coastal waters. We hypothesized that species composition would be related to water quality conditions, and that fatty acid profiles of seston would relate to zooplankton species composition. Fatty acid composition may help interpret trophic relations in aquatic systems, because it is the most important molecules transferred across the plant-animal interface in aquatic food webs (Brett et al. 2009).

\section{MATERIALS AND METHODS}

\section{STUDY SITE AND SAMPLE COLLECTION}

Three sampling locations namely Kuala Juru (N 05 18.6', E 100 24.114'), Jelutong (N 05 23.176', E 100 19.293'), and Jerejak (N 05 18.067, E 100 18.702) were identified for this study (Figure 1). These locations were chosen based on the different anthropogenic activities on shore and were visited on five sampling occasions from July 2009 until April 2011. Kuala Juru is located in the vicinity of Prai Industrial Zone and has been receiving tremendous amount of organic wastes through Sungai Juru, Seberang Perai and also identified as one of the most polluted rivers in Malaysia. Sungai Juru was considered as a 'dying river' because the catchments are made up of industrial and residential area that contributes pollutants to the receiving waters. Jelutong on the other hand is associated with urban activities; the selected location has also been receiving substantial amounts of organic wastes, particularly in the form of urban sewage. Jerejak is relatively clean and was considered as a reference site.

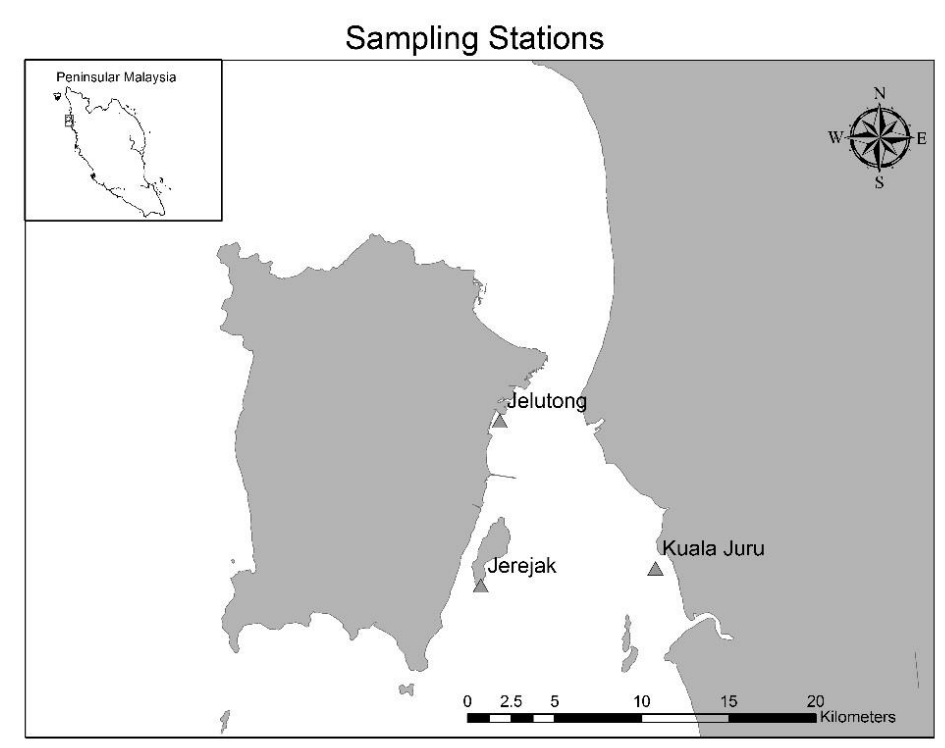

FIGURE 1. Map showing the sampling locations at Penang Island coastal waters 
During the sampling events, some water quality parameters were measured in-situ. Temperature, salinity, $\mathrm{pH}$ and dissolved oxygen (DO) were measured using a Model HI 9828 Hanna Multiparameter Water Quality Meter probe while turbidity was measured using a Model HI 98703 Hanna Turbidity Meter. Water samples were collected at $0.5 \mathrm{~m}$ below the surface and at mid-depth using a 2.2 L capacity Alpha Water Sampler. Nitrate was determined through cadmium reduction. Phosphate was measured by the ascorbic acid method. The concentration of ammonia-N was measured through the ammonia lowlevel indophenol method. These parameters, measured according to the standard methods by APHA (1998) were used for the determination of exogenous environmental factors that affect the monthly distribution and abundance of zooplankton.

Zooplankton samples were collected using a WP-2 plankton net $(165 \mathrm{~cm}$ long, $50 \mathrm{~cm}$ mouth diameter with a $200 \mu \mathrm{m}$ mesh size) (Sameoto et al. 2000). The net was towed at a slow speed for about $5 \mathrm{~min}$ at the surface. The towing speed was slow to ensure that the maximum amount of water enters through the mouth of the net. This is important for better filtration and the gear used can withstand the strain. For every tow, the volume $\left(\mathrm{m}^{3}\right)$ of filtered water was recorded. A fraction of the filtered water samples was used to get seston (Hutchens Jr. et al. 2017; Ravet et al. 2010; Tiselius et al. 2012) for fatty acid analysis. The zooplankton samples were transferred into $1 \mathrm{~L}$ polyethylene bottles and preserved with $5 \%$ formaldehyde solution for identification and enumeration. In the laboratory, Rose Bengal solution was added to the zooplankton sample to aid in the taxonomic identification. A 10-25 mL sub-sample was taken from 500 $\mathrm{mL}$ well-mixed zooplankton sample by using a pipette for identification and enumeration. Zooplankton in the subsample was identified and enumerated in a Bogarov tray under dissecting microscope. Species identification was carried out to the genus level using several taxonomic references including Day (1967a, 1967b), Gosner (1971), Keen (1971), Lincoln and Sheals (1979), Morris (1973) and Naylor (1972). The counting was done under the microscope and when the specimen of the particular group was encountered, a tally mark was made on the sheet. The results for zooplankton relative abundance were expressed in the percentage of total abundance of each zooplankton group.

\section{FATTY ACID ANALYSIS}

The fatty acid analysis was carried out using direct transesterification method as described by Abel et al. (1963) with some modifications. The seston samples were filtered by using Whatman filter papers before freeze drying. Freeze dried cells of 10-20 mg were weighed into methanolisis tubes. Two $\mathrm{mL}$ of chloroform was added, followed by the addition of $2 \mathrm{~mL}$ a mixture of methanol:sulphuric acid (85:15) into each of the methanolisis tubes. The samples were exposed to nitrogen gas for about $30 \mathrm{~s}$, then, they were vortex for $2 \mathrm{~min}$. The tubes were closed tightly and were placed on the heater block at $100{ }^{\circ} \mathrm{C}$ for $1 \mathrm{~h}$ and $30 \mathrm{~min}$. After the samples have cooled down, $1 \mathrm{~mL}$ of distilled water was added into each methanolisis tube and they were vortex for about 1 min. The samples were left for $4 \mathrm{~h}$ for separation process. There were 2 layers of solution formed, which were the choloroform and methyl ester group. Methyl ester group was in the bottom layer. A pinch of $\mathrm{Na}_{2} \mathrm{SO}_{4}$ was put into a screw cap bottle. The bottom layer which was the methyl ester group was then transferred into the screw cap bottle using pasteur pipette and was left for a few min. A volume of $0.75 \mathrm{~mL}$ samples were transferred into the gas chromatography bottles by using micropipette. The bottles were closed and wrapped with parafilm. Then, the samples were kept in $4{ }^{\circ} \mathrm{C}$ until GC analysis.

Fatty acid methyl esters (FAMEs) were separated and quantified by a gas chromatograph (GCMS-2010, Shimadzu, Japan). Nitrogen was used as the carrier gas, and the temperature programming was maintained at 21 ${ }^{\circ} \mathrm{C}$ for $30 \mathrm{~min}$. The injector and detector temperatures were set at 250 and $260{ }^{\circ} \mathrm{C}$, respectively. Menhaden oil and Supelco 37 Component FAME Mix were used as the standards for fatty acid identification by the comparison of the peak retention times between the samples and standards at a ratio of $3: 1$. The concentration of the fatty acids was estimated from the peak area on the chromatogram using 99\% methyl enanthate (C7:0) (Sigma Aldrich, USA) as an internal standard.

\section{STATISTICAL ANALYSIS}

Analysis of variance (One-way ANOVA) and the Tukey HSD tests were used to determine statistically significant differences $(\mathrm{P}<0.01)$ of the parameters between sampling stations. The data were transformed to natural logarithms $(\log 10(x))$ to normalise them. Spearman's correlations were performed to correlate the water quality parameters with zooplankton abundance and diversity. The analysis was performed using SPSS (PASW Statistics 17) and Microsoft Excel 2003 packages.

\section{RESULTS AND DISCUSSION}

Water quality parameters measured for each station is shown in Table 1. Based on Malaysia Marine Water 
Quality Criteria and Standard (MWQCS), Kuala Juru and
Jelutong were categorized as polluted, and Jerejak as slightly polluted.

TABLE 1. Physico- chemical parameters (mean \pm s.d) at all sampling stations throughout the study period

\begin{tabular}{lccc}
\hline \multirow{2}{*}{ Physico-chemical parameters } & \multicolumn{3}{c}{ Sampling stations } \\
\cline { 2 - 4 } & Kuala Juru & Jelutong & Jerejak \\
\hline DO $(\mathrm{mg} / \mathrm{L})$ & $6.83 \pm 0.02$ & $2.98 \pm 0.48$ & $3.74 \pm 0.09$ \\
$\mathrm{pH}$ & $31.52 \pm 1.14$ & $7.47 \pm 0.02$ & $7.52 \pm 0.02$ \\
Temperature $\left({ }^{\circ} \mathrm{C}\right)$ & $24.66 \pm 0.02$ & $30.31 \pm 0.36$ & $31.16 \pm 0.14$ \\
Salinity $(\mathrm{ppt})$ & $3.53 \pm 0.31$ & $28.38 \pm 0.02$ & $29.85 \pm 0.02$ \\
BOD $(\mathrm{mg} / \mathrm{L})$ & $6.82 \pm 0.45$ & $2.11 \pm 0.19$ & $0.45 \pm 0.13$ \\
Turbidity $(\mathrm{NTU})$ & $4.02 \pm 0.28$ & $2.64 \pm 0.56$ & $1.47 \pm 0.42$ \\
Chlorophyll- $a(\mu \mathrm{g} / \mathrm{L})$ & $0.34 \pm 0.05$ & $3.62 \pm 0.35$ & $1.86 \pm 0.18$ \\
Ammonium $(\mathrm{mg} / \mathrm{L})$ & $0.034 \pm 0.03$ & $0.26 \pm 0.06$ & $0.06 \pm 0.02$ \\
Nitrate-nitrogen $(\mathrm{mg} / \mathrm{L})$ & $0.030 \pm 0.02$ & $0.032 \pm 0.01$ & $0.013 \pm 0.01$ \\
Ortho-phosphate $(\mathrm{mg} / \mathrm{L})$ & & $0.020 \pm 0.001$ & $0.005 \pm 0.001$ \\
\hline
\end{tabular}

Arthropoda was the main phyla which contributed $78.80 \%$ of zooplankton total abundance, followed by Chordata (9.10\%), Cycliophora (6.12\%), Actinopoda
(2.08\%), Rotifera (2.57\%), Annelida (0.63\%), Cnidaria $(0.51 \%)$, and Chaetognatha $(0.19 \%)$ (Figure 2$)$.

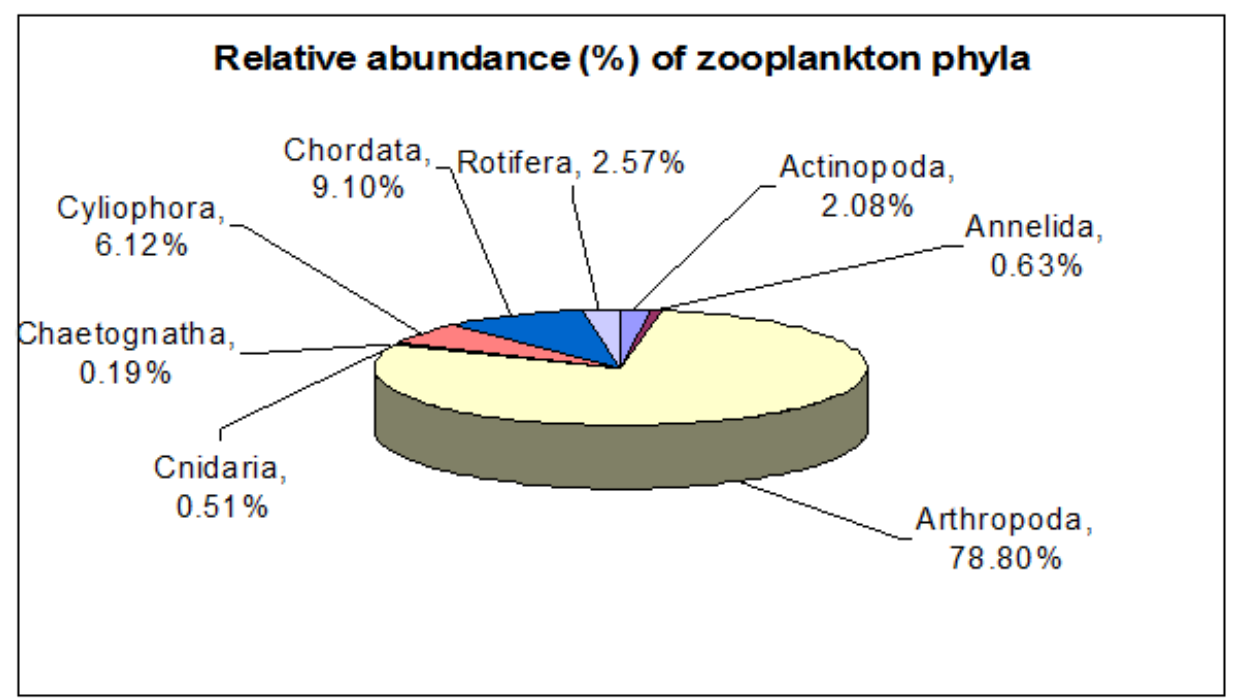

FIGURE 2. Relative abundance (\%) of zooplankton phyla recorded throughout the study period 
At Kuala Juru and Jerejak Stations, the most dominant zooplankton found were copepod nauplii, Oithona spp. and Acartia spp. (Table 2). Copepoda, Oithona spp. and Acartia spp. under the phylum Arthropoda, were the most dominant phylum in this study (Figure 2). At Jelutong Station, Acartia spp., Pseudocyclopia spp., and Favella spp. were dominant (Table 2). No significant difference of Copepoda abundance ( $p>0.05$, One-way ANOVA) between stations. Acartia spp. was found at all sampling stations and the abundance was not significantly different between stations ( $\mathrm{p}>0.05$, One-Way ANOVA). Favella spp. abundance was not significantly different between stations ( $\mathrm{p}>0.05$, One-way ANOVA).

TABLE 2. Zooplankton species composition and relative abundance (\%) at sampling sites

\begin{tabular}{|c|c|c|c|}
\hline \multirow{2}{*}{ Species } & \multicolumn{3}{|c|}{ Sampling stations } \\
\hline & Kuala Juru & Jelutong & Jerejak \\
\hline Acanthomatron spp. & - & - & + \\
\hline Acartia spp. & ++ & ++ & +++ \\
\hline Acrocalanus spp. & - & - & + \\
\hline Ameira spp. & + & + & + \\
\hline Barnacle nauplii & + & + & + \\
\hline Benthomisphria spp. & + & + & + \\
\hline Brachionus spp. & - & + & - \\
\hline Candacia spp. & - & + & + \\
\hline Bradycalanus spp. & + & - & + \\
\hline Copepod nauplii & +++ & + & +++ \\
\hline Cypris larvae & + & - & - \\
\hline Daphnia spp. & + & + & - \\
\hline Diaixis spp. & + & + & - \\
\hline Eurytemora spp. & + & ++ & - \\
\hline Eutermina spp. & + & - & - \\
\hline Favella spp. & + & ++ & ++ \\
\hline Fish egg & + & - & + \\
\hline Fish larvae & - & + & + \\
\hline Macrosetella spp. & - & + & + \\
\hline Halteria spp. & + & - & - \\
\hline Jellyfish larvae & + & - & - \\
\hline Leptomedusa spp. & + & - & + \\
\hline Megalops & + & - & - \\
\hline Metridia spp. & + & - & - \\
\hline Oikopleura spp. & + & ++ & + \\
\hline Oithona spp. & ++ & + & ++ \\
\hline Palpophria spp. & - & + & + \\
\hline Phaenna spp. & + & - & - \\
\hline Pontodora pelagica & + & - & + \\
\hline Pseudocyclopia spp. & + & ++ & + \\
\hline Rhincalanus spp. & + & + & + \\
\hline Rotifer spp. & - & + & + \\
\hline Sagitta spp. & - & + & - \\
\hline Ryocalanus spp. & + & + & - \\
\hline Shrimp nauplii & + & + & ++ \\
\hline Stephos spp. & - & - & + \\
\hline Tharybis spp. & - & + & + \\
\hline Zoea & + & + & + \\
\hline
\end{tabular}

$(-)$ : absent; $(+)$ : rare $(1.00-30 \%) ;(++)$ : common $(31-60.00 \%) ;(+++)$ : abundant $(61-100.00 \%)$ 
The most dominant zooplankton found were copepod nauplii. Previous studies along the Straits of Malacca by Johan et al. (2000), Wei (2012) and Yoshida et al. (2006) also reported Arthropoda as the most dominant group. Copepods are dominant zooplankton community of aquatic ecosystems (Davies \& Otene 2009; Garrison 2005; Rezai et al. 2004; Wei 2012; Yoshida et al. 2006). Oithona spp. were encountered and dominant at all sampling stations, and the abundance was significantly different between Kuala Juru and Jelutong stations ( $\mathrm{p}<0.05$, Tukey's Test). Although those two stations shared similar water quality conditions, the spatial variation in Oithona spp. abundance most probably controlled by food availability and possibly predation pressure (Castellani et al. 2007). Acartia and Oithona were among the most commonly found zooplankton in mangrove estuary, Malaysia (Chew \& Chong 2011).

\section{INTERACTION BETWEEN ZOOPLANKTON DISTRIBUTION AND WATER QUALITY PARAMETERS}

Zooplankton abundance was negatively correlated with BOD, turbidity (NTU), and chlorophyll-a (Table 3). Abundance might be low at poor water quality such as water with high BOD, nutrients, and turbidity. High turbidity reduces the light intensity thus photosynthesis by phytoplankton decreased. Hence, reduced abundance of phytoplankton will reduce the zooplankton population, which graze on phytoplankton (Tian et al. 2017). Zooplankton abundance showed negative correlation with nitrate-nitrogen concentration. However, Sudara and Udomkit (1984) in their research at Gulf of Thailand found that distribution of zooplankton was positively influenced by the amount of nutrients available. The negative correlation between zooplankton abundance and nitrate-nitrogen might happen because of this nutrient was a limiting nutrient in seawater, which controls the primary productivity of phytoplankton. This nutrient might affect the phytoplankton abundance; however the freshwater input from land might contribute to high turbidity (due to association of suspended matter such as silt, clay, organic, and inorganic matter). Fluctuation in surface seawater productivity is a result of nutrients fluxes flow originated from both natural and anthropogenic origins that change the water quality (Idrus et al. 2017). High turbidity was unfavorable to phytoplankton. Choi et al. (2011) and Tian et al. (2017) reported that spatial and temporal variations of water quality had no direct impact on zooplankton community, but indirectly influence zooplankton through phytoplankton. Zooplankton abundance normally positively correlated with phytoplankton abundance, depending on the zooplankton dominant genera's diets (Brett et al. 2009; Villa et al. 1997).

Zooplankton abundance was positively correlated with DO (Table 3) (Wan Maznah et al. 2018). DO affects zooplankton communities through their growth rates, reproduction, and metabolic rates (Carter \& Schindler 2012; Olson \& Daly 2013). DO has been reported as one of the most important factors limiting the occurrence of certain groups of zooplankton, for example Rotifera (Arora \& Mehra 2003). The relative abundance of rotifers was significantly higher in non-polluted region of a water body (Tian et al. 2017). This correlation was not in agreement with the findings by Santhakumari (1991) in the West Coast of India, where the biomass of zooplankton was at its peak during low availability of DO and also low temperature.

TABLE 3. Spearman's correlation coefficients between biological parameters and water quality parameters

\begin{tabular}{lcc}
\hline \multicolumn{1}{c}{ Water quality parameters } & Zooplankton abundance & Zooplankton diversity \\
\hline $\mathrm{pH}$ & $-0.339^{*}$ & $-.330^{*}$ \\
Temperature & $0.351^{*}$ & $.388^{* *}$ \\
Salinity & -0.005 & -0.040 \\
$\mathrm{DO}$ & $0.464^{* *}$ & $.470^{* *}$ \\
$\mathrm{NH}_{4}-\mathrm{N}$ & -0.132 & -0.161 \\
$\mathrm{NO}_{3}-\mathrm{N}$ & $-0.475^{* *}$ & $-.500^{* *}$ \\
$\mathrm{PO}_{4}-\mathrm{P}$ & -0.008 & 0.147 \\
Turbidity & -0.136 & -0.070 \\
BOD & $-0.430^{* *}$ & $-0.426^{* *}$ \\
Chlorophyll- $a$ & -0.068 & -0.117 \\
\hline
\end{tabular}


Results showed that the diversity index of zooplankton at all sampling locations were quite low (Figure 3). The magnitude of species diversity is sensitive to both the number of species present and the degree of dominance (Aquino et al. 2008; Wan Maznah \& Mansor 2002). Low number of dominant taxa (all the taxa were evenly distributed among the population) leads to high species diversity. This is conformed to the present study where low diversity were recorded at stations and sampling events with high dominancy of a particular taxa. For example, at Kuala Juru Station during first two sampling sessions $\left(H^{\prime}=1.15\right)$, Oikopleura spp. and copepod nauplii were highly abundant (relative abundance of $27.82 \%$ and $59.73 \%$, respectively)

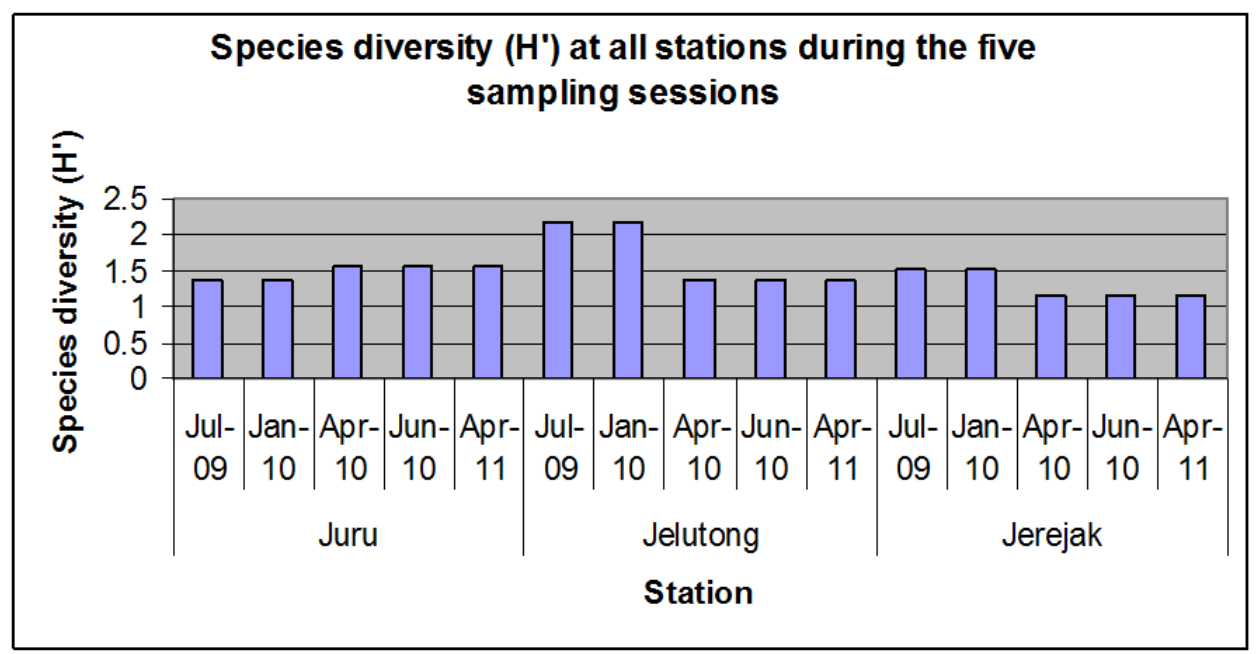

FIGURE 3. Diversity index (H') of zooplankton at all stations during five sampling sessions

Zooplankton diversity was positively correlated with $\mathrm{DO}$, and temperature, but negatively correlated with $\mathrm{pH}$, BOD, and nitrate-nitrogen. According to Madhupratap and Onbe (2004), zooplankton species diversity was low in the polluted water region.

\section{SESTON FATTY ACID CONTENT}

Palmitic acid was quite high at all stations (Table 4). Brepohl (2005) noted that high composition of SAFA might be attributed by nutrient availability. Myristic (C14:0) and stearic (C18:0) acids were detected at all stations and sampling occasions. This was similar to the study by Brepohl (2005), where palmitic, myristic and stearic acids were the SAFA detected regularly on seston. SAFA was the most dominant and regularly occurred at all stations which might be contributed by the dominance of copepods (Brepohl 2005). In this study, SAFA was more dominant than PUFA at all stations, as reported by Tiselius et al. (2012), might be due to its resistant to biological, physical and chemical factors in the water. SAFA is more resistant to factors such as photolytic (chemical degradation by light), biological and chemical degradation compared to PUFA (Kattneret et al. 1981). Thus, SAFA would concentrate in seston, which then would be consumed by zooplankton. 
TABLE 4. Composition and proportion of fatty acid as expressed by percentage of total fatty acid (\%) in plankton

\begin{tabular}{|c|c|c|c|}
\hline \multirow{2}{*}{ Fatty acid } & \multicolumn{3}{|c|}{ Sampling stations } \\
\hline & Kuala Juru & Jelutong & Jerejak \\
\hline \multicolumn{4}{|l|}{ Saturated (SFA) } \\
\hline $\mathrm{C} 12: 0$ & 0.52 & 3.88 & 7.81 \\
\hline $\mathrm{C} 14: 0$ & 6.46 & 4.86 & 10.45 \\
\hline $\mathrm{C} 15: 0$ & 2.056 & 0.8 & 0 \\
\hline $\mathrm{C} 16: 0$ & 30.52 & 45.21 & 30.65 \\
\hline $\mathrm{C} 17: 0$ & 1.46 & 9.41 & 3.83 \\
\hline C18:0 & 12.25 & 5.31 & 10.43 \\
\hline $\mathrm{C} 20: 0$ & 2.67 & 2.64 & 3.30 \\
\hline $\mathrm{C} 24: 0$ & 1.41 & 0 & 0 \\
\hline \multicolumn{4}{|l|}{ Monounsaturated (MUFA) } \\
\hline $\mathrm{C} 14: 1$ & 8.10 & 0 & 0 \\
\hline C16:1 & 7.79 & 1.23 & 2.95 \\
\hline $\mathrm{C} 18: \ln 9 \mathrm{c}$ & 2.79 & 8.53 & 6.49 \\
\hline $\mathrm{C} 18: \ln 9 \mathrm{t}$ & 0 & 2.50 & 0 \\
\hline C20:1n9 & 0 & 0.37 & 0 \\
\hline $\mathrm{C} 24: \ln 9$ & 0.12 & 5.36 & 2.12 \\
\hline \multicolumn{4}{|l|}{ Polyunsaturated (PUFA) } \\
\hline $\mathrm{C} 14: 2$ & 2.38 & 0 & 0 \\
\hline $\mathrm{C} 18: 2 \mathrm{n} 6 \mathrm{c}$ & 4.96 & 0.59 & 1.42 \\
\hline $\mathrm{C} 18: 2 \mathrm{n} 6 \mathrm{t}$ & 0 & 2.41 & 5.37 \\
\hline $\mathrm{C} 18: 3 \mathrm{n} 3 \mathrm{c}$ & 3.10 & 0 & 0 \\
\hline C20:2 & 0.37 & 0 & 3.10 \\
\hline $\mathrm{C} 20: 3 \mathrm{n} 3$ & 0 & 0.598 & 7.13 \\
\hline C20:3n6 & 0.99 & 0 & 0 \\
\hline C20:5n 3 & 3.88 & 2.79 & 4.09 \\
\hline $\mathrm{C} 22: 2$ & 2.24 & 1.67 & 1.43 \\
\hline $\mathrm{C} 22: 6 \mathrm{n} 3$ & 5.29 & 2.18 & 0 \\
\hline
\end{tabular}

The presence of MUFA might be attributed by the presence of Daphnids, which tend to accumulate more MUFA for storage, bioconversion and structure (Burns et al. 2011). The important PUFA found in this study was linolenic acid (C18:2n6c), as reported by other studies such as by Navarra and Brett (1997). Linolenic acid was detected on seston during all sessions at Juru Station, but rarely occurred at other stations. Its proportion was low, 
and PUFA in seston was reported as a limiting factor for growth and reproduction in cladocerans and copepods (Tiselius et al. 2012). Docosahexenoic acid (C22:6n3) or DHA was the only HUFA found in the present study. Its concentration was quite low at all locations. In the present study, cladocerans and EPA were recorded at all sampling stations. Cladocerans were reported to have relatively greater content of EPA (Persson \& Vrede 2006), thus, might justify their wide distribution in relation with EPA in seston.

The limitation of nutrients influences the changes in fatty acid composition (Grosse et al. 2019). Brepohl (2005) and Jónasdóttir (2019) reported that the decrease of PUFA increase SAFA and MUFA in the water column. Overall, this trend is parallel to this study. Carnivorous crustacean, reported to have richer in PUFAs (Arts et al. 2009) were recorded in limited number, corresponding to lower seston PUFA content. The large input of nutrients from land might trigger the phytoplankton growth. However, nutrient limitation affects the phytoplankton which then consumed by zooplankton. The intensity of interaction between phytoplankton and zooplankton is greatly influenced by the trophic states of a waterbody (Tian et al. 2017). The transformation impact of fatty acid in plankton is highly variable at coastal waters, and these situations are more complicated since both phytoplankton and zooplankton are complex in taxonomic composition and each of the group has its own ecophysiological traits (Ciros-Pérez et al. 2015; Steinberg \& Landry 2017). Variability in nutrient supply and synthesized biochemical molecules (i.e. fatty acids, amino acids) determines phytoplankton abundance, which is part of seston population and prey quality for zooplankton (Chi et al. 2018). Although this study did not measure fatty acid content on individual groups of zooplankton, fatty acid composition in seston could be related to zooplankton groups abundance (Tiselius et al. 2012).

Whether a specific fatty acid can limit the zooplankton growth and reproduction depend on their nutritional requirements and also the diet's essential nutrient content (Anderson \& Pond 2000; Chi et al. 2018; McMeans et al. 2015). Little is known about the fatty acid composition in zooplankton and their nutritional demands of different taxa (Persson \& Vrede 2006).

Copepods select and catch their food (DeMott 1986), and they prefer large particles (Adrian \& Scheiner-Olt 1999). The different grazing behaviors have contrasting impacts on the fatty acid profile of mesozooplankton and phytoplankton community as well, subsequently; the changes in fatty acid profile affect the growth of zooplankton (Brepohl 2005). Correlations between the EPA and DHA contents of phytoplankton and the growth rates of zooplankton have been reported in the laboratory and in nature (Gulati \& Demote 1997; Jónasdóttir 2019). Based on biomarkers as noted by Desvilettes et al. (1997), and Hamm and Rousseou (2003); palmitic acid (C16:0), docosahexenoic acid/DHA (C22:6n3), andoleic acid (C18:1n9c) are derived from flagellates and dinoflagellates. Although our study did not include major phytoplankton blooms, we assume that the dominant zooplankton grazed on flagellates and dinoflagellates. Most marine zooplankton are unable to convert precursor fatty acids, thus they have to obtain longer-chained fatty acids from their diet (Persson \& Vrede 2006).

Variation of fatty acid content might be contributed by differences in fatty acid composition in the seston, and mesozooplankton is the main conduit for fatty acid transfer (Tiselius et al. 2012). Grazing may affect the fatty acid composition in two ways as proposed by Gulati and Demott (1997). Firstly, zooplankton change the microalgae physiological state by giving impact on nutrient availability. Secondly, the grazing effect of zooplankton may change the taxonomic composition of zooplankton by reducing the occurrence of certain species. This study may be beneficial for aquatic resources management as the variability in plankton fatty acid composition may be an indicator of larval fish habitat quality (Lichti et al. 2017). As a key trophic vector, zooplankton is able to concentrate and store phytoplankton-based lipids in the seston, thus, channelize these nutritional compounds towards the organisms at higher trophic levels (Jónasdóttir 2019).

\section{CONCLUSION}

Temperature, $\mathrm{pH}, \mathrm{DO}$, nitrate, and BOD were among the water quality parameters that affect the abundance and diversity of zooplankton in this study. The fatty acid methyl esters (FAMEs) detected on seston was SAFA, MUFA, PUFA and HUFA. Zooplankton community was influenced by water quality and seston characteristics.

\section{ACKNOWLEDGEMENTS}

This study was supported by the Research University Grant Scheme (1001/PBIOLOGI/815053) from Universiti Sains Malaysia.

\section{REFERENCES}

Abel, K., Deschmertzing, H. \& Peterson, J.I. 1963. Classification of microorganisms by analysis of chemical composition. Journal of Bacteriology 85(5): 1039-1044. 
Adrian, R. \& Schneider-Olt, B. 1999. Top-down effects of crustacean zooplankton on pelagic microorganisms in a mesotrophic lake. Journal of Plankton Research 21(11): 2175-2190.

Anderson, T.R. \& Pond, D.W. 2000. Stoichiometric theory extended to micronutrients: Comparison of the roles of essential fatty acids, carbon, and nitrogen in the nutrition of marine copepods. Limnology and Oceanography 45(5): 1162-1167.

APHA. 1998. Standard Methods for the Examination of Water and Wastewater. 20th ed. Washington: American Public Health Association.

Aquino, M.R.Y., Cho, C.D., Cruz, M.A.S., Saguiguit, M.A.G. \& Papa, R.D.S. 2008. Zooplankton composition and diversity in Paoay Lake, Luzon Is., Philippines. Philippine Journal of Science 137(2): 169-177.

Arora, J. \& Mehra, N.K. 2003. Seasonal dynamics of rotifers in relation to physical and chemical conditions of the river Yamuna (Delhi) India. Hydrobiologia 491(1): 101-109.

Arts, M.T., Brett, M.T. \& Kainz, M.J. 2009. Lipids in Aquatic Ecosystems. New York: Springer.

Bergé, J.P. \& Barnathan, G. 2005. Fatty acids from lipids of marine organisms: Molecular diversity, roles as biomarkers, biologically active compounds, and economical aspects. Advances in Biochemical Engineering/Biotechnology 96: 49-125.

Brepoh1, D.C. 2005. Fatty acid distribution in marine, brackish and freshwater plankton during mesocosm experiments. Christian-Albrechts-Universitat. Ph.D. Thesis (Unpublished).

Brett, M.T., Müller-Navarra, D.C. \& Persson, J. 2009. Crustacean zooplankton fatty acid composition. In Lipids in Aquatic Ecosystems, edited by Arts, M.T. Arts. Berlin, Heidelberg: Springer. pp. 115-146.

Burns, C.W., Brett, M.T. \& Schallenberg, M. 2011. A comparison of the trophic transfer of fatty acids in freshwater plankton by cladocerans and calanoid copepods. Freshwater Biology 56(5): 889-903.

Carter, J.L. \& Schindler, D.E. 2012. Responses of zooplankton populations to four decades of climate warming in lakes of southwestern Alaska. Ecosystems 15(6): 1010-1026.

Castellani, C., Irigoien, X., Harris, R.P. \& Holliday, R.P. 2007. Regional and temporal variation of Oithona spp. biomass, stage structure and productivity in the Irminger Sea, North Atlantic. Journal of Plankton Research 29(12): 1051-1070.

Chew, L.L. \& Chong, V. 2011. Copepod community structure and abundance in a tropical mangrove estuary, with comparisons to coastal waters. Hydrobiologia 666(1): 127143.

Chi, X., Javidpour, J., Sommer, U. \& Mueller-Navarra, D. 2018. Tracking fatty acids from phytoplankton to jellyfish polyps under different stress regimes: A three trophic levels experiment. Frontiers in Ecology Evolution 6: 118.
Choi, W.R., Fang, L.S., Wang, W.H. \& Tew, K.S. 2011. Environmental influence on coastal phytoplankton and zooplankton diversity: A multivariate statistical model analysis. Environmental Monitoring and Assessment 184(9): 5679-5688

Ciros-Pérez, J., Ortega-Mayagoitia, E. \& Alcocer, J. 2015. The role of ecophysiological and behavioral raits in structuring the zooplankton assemblage in a deep, oligotrophic, tropical lake. Limnology Oceanography 60(6): 2158-2172.

Colombo, S., Parrish, C. \& Whiticar, M. 2016. Fatty acid stable isotope signatures of molluscs exposed to finfish farming outputs. Aquaculture Environment Interactions 8: 611-617.

Davies, O.A. \& Otene, B.B. 2009. Zooplankton community in Minichinda Stream, Port Harcourt, Rivers State, Nigeria. European Journal of Scientific Research 26(4): 490-498.

Day, J.H. 1967a. A Monograph on the Polychaeta of Southern Africa. Part 1. London: Trustees of the British Museum (Natural History).

Day, J.H. 1967b. A Monograph on the Polychaeta of Southern Africa. Part 11. London: Trustees of The British Museum (Natural History).

Desvilettes, C.H., Bourdier, G., Amblard, C.H. \& Barth, B. 1997. Use of fatty acids for the assessment of zooplankton grazing on bacteria, protozoans and microalgae. Freshwater Biology 38(3): 629-637.

Garrison, T. 2005. Oceanography: An Invitation to Marine Science. 5th ed. California: Brooks/Cole-Thomson Learning.

Gosner, K.L. 1971. Guide to Identification of Marine and Estuarine Invertebrates. New Jersey: John Wiley \& Sons, Inc. p. 303.

Grosse, J., Brussaard, C. \& Boschker, H. 2019. Nutrient limitation driven dynamics of amino acids and fatty acids in coastal phytoplankton. Limnology and Oceanography 64(1): 302-316

Gulati, R.D. \& Demott, W.R. 1997. The role of food quality for zooplankton: Remarks on the state-of-the-art, perspectives and priorities. Freshwater Biology 38(3): 591-596.

Hamm, C.E. \& Rousseou, V. 2003. Composition, assimilation and degradation of phaeocystis globosa-derived fatty acids in the North Sea. Journal of Sea Research 50(4): 271-283.

Idrus, F.A., Chong, M.D., Rahim, N.S., Mohd Basri, M. \& Musel, J. 2017. Physicochemical parameters of surface seawater in Malaysia exclusive economic zones off the coast of Sarawak. Borneo Journal of Resource Science and Technology 7(1): 1-10.

Johan, I., Idris, A.G., Norlita, I. \& Mohd Affandy, B. 2000. The zooplankton community at Port Klang and the surrounding waters. In Towards Sustainable Management of the Straits of Malacca, edited by Shariff, M., Yusoff, F.M., Gopinath, N., Ibrahim, H.M. \& Nik Mustapha, R.A. Serdang: Universiti Putra Malaysia. pp. 179-187.

Jónasdóttir, S.H. 2019. Fatty acid profiles and production in marine phytoplankton. Marine Drugs 17(3): 151-171. 
Kattner, G., Krause, M. \& Thrams, J. 1981. Lipid composition of some typical North Sea copepods. Marine Ecology Progress Series 4: 69-74.

Keen, A.M. 1971. Seashells of tropical West Africa. California: Stanford University Press. p. 1064

Lichti, D.A., Rinchard, J. \& Kimmel, D.G. 2017. Changes in zooplankton community, and seston and zooplankton fatty acid profiles at the freshwater/saltwater interface of the Chowan River, North Carolina. Peer J. 16(5): e3667.

Lincoln, R.J. \& Sheals, G. 1979. Invertebrate Animal Collection and Preservation. United Kingdom: Cambridge University Press. pp. 46-136.

Madhupratap, M. \& Onbe, T. 2004. Structure and species diversity of the zooplankton community of the Inland Sea of Japan. Estuarine, Coastal, and Shelf Science 23(5): 725-737.

McMeans, B.C., Koussoroplis, A.M. \& Kainz, M.J. 2015. Effects of seasonal seston and temperature changes on lake zooplankton fatty acids. Limnology and Oceanography 60(2): 573-583.

Morris, P.A. 1973. A Field Guide to Shells of the Atlantic and Gulf Coast and the West Indies. Boston: Houghton Miffin Co. p. 329.

Napolitano, G.E., Pollero, R.J., Gayoso, A.M., Macdonald, B.A. \& Thompson, R.J. 1997. Fatty acid as trophic markers of phytoplankton blooms in the Bahia Blanca estuary (Buenos Aires, Argentina) and in Trinity Bay (Newfoundland, Canada). Biochemical Systematics and Ecology 25(8): 739755.

Naylor, E. 1972. British Marine Isopods. Keys and Notes for the Identification of the Species. London: Synopses of British Fauna, Academic Press. p. 86.

Olson, M.B. \& Daly, K.L. 2013. Micro-grazer biomass, composition and distribution across prey resource and dissolved oxygen gradients in the far eastern tropical north Pacific Ocean. Deep Sea Research Part I: Oceanographic Research Papers 75: 28-38.

Persson, J. \& Vrede, T. 2006. Polyunsaturated fatty acids in zooplankton: Variation due to taxonomy and trophic position. Freshwater Biology 51(5): 887-900.

Ravet, J.L., Brett, M.T. \& Arhonditsis, G.B. 2010. The effects of seston lipids on zooplankton fatty acid composition in Lake Washington, Washington, USA. Ecology 91(1): 180190.

Rezai, H., Yusoff, F.M., Arshad, A., Kawamura, A., Nishida, S. \& Ross, O.B.H. 2004. Spatial and temporal distribution of copepods in the Straits of Malacca, Zoological Studies 43: 486-497.

Sameoto, D., Wiebe, P., Runge, J., Postel, L., Dunn, J., Miller, C. \& Coombs, S. 2000. Collecting zooplankton. In ICES Zooplankton Methodology Manual, edited by Harris, R., Wiebe, P., Lenz, J., Skjoldal, H.R. \& Hauntley, M. London: Academic Press. pp. 55-82.
Santhakumari, V. 1991. Zooplankton standing stock and community structure along Karnataka Coast, west coast of India. Journal of the Indian Fisheries Association 21:21-30.

Steinberg, D.K. \& Landry, M.R. 2017. Zooplankton and the ocean carbon cycle. Annual Review of Marine Science 9: 413-444.

Sudara, S. \& Udomkit, A. 1984. Distribution of important zooplankton in the inner part of the gulf of Thailand. Proceeding of the 3rd Seminar on The Water Quality and the Quality og Living Resources in Thai Waters. pp. 425-435.

Tian, W., Zhang, H., Zhang, J., Zhao, L., Miao, M. \& Huang, H. 2017. Responses of zooplankton community to environmental factors and phytoplankton biomass in Lake Nansihu, China. Pakistan Journal of Zoology 49(2): 461-470.

Tiselius, P., Hansen, B.W. \& Calliari, D. 2012. Fatty acid transformation in zooplankton: From seston to benthos. Marine Ecology Progress Series 446: 131-144.

Villa, H., Quintela, J., Coelho, M.L., Icely, J.D. \& Andrade, J.D. 1997. Phytoplankton biomass and zooplankton abundance on the south coast of Portugal (Sagres), with special reference to spawning of Loligo vulgaris. Scientia Marina 61(2): 123-129.

Wan Maznah, W.W. \& Mansor, M. 2002. Aquatic pollution assessment based on attached diatom communities in the Pinang River Basin, Malaysia. Hydrobiologia 487(1): 229241.

Wan Maznah, W.W., Intan, S., Sharifah, R. \& Lim, C.C. 2018. Lentic and lotic assemblages of zooplankton in a tropical reservoir, and their association with water quality conditions. International Journal of Environmental Science and Technology 15(3): 533-542.

Wei, C.J. 2012. Zooplankton community structure in the coastal waters of Manjung, Perak and Penang National Park, Penang. School of Biological Sciences. Universiti Sains Malaysia. MSc Thesis (Unpublished).

Werbrouck, E., Tiselius, P., Van Gansbeke, D., Cervin, G., Vanreusel, A. \& De Troch, M. 2016. Temperature impact on the trophic transfer of fatty acids in the congeneric copepods Acartia tonsa and Acartia clausi. Journal of Sea Research 112: 41-48.

Yoshida, T., Toda, T., Yusoff, M. \& Toman, B.H.R. 2006. Seasonal variation of zooplankton community in the coastal waters of the Straits of Malacca. Coastal Marine Science 30(1): 320-327.

Wan Maznah, W.O.*, Nur 'Ain Kassim \& Zubir Din

School of Biological Sciences

Universiti Sains Malaysia

11800 Penang

Malaysia 
Wan Maznah, W.O.*

Centre for Marine and Coastal Studies (CEMACS)

Universiti Sains Malaysia

11800 Penang

Malaysia

Wan Maznah, W.O.*

River Engineering and Urban Drainage Centre (REDAC)

Universiti Sains Malaysia

Seri Empangan

14300 Nibong Tebal, Penang

Malaysia
*Corresponding author; email: wmaznah@usm.my

Received: 25 February 2020

Accepted: 8 October 2020 